\title{
DEFINING ILLEGAL INSIDER TRADING- LESSONS FROM THE EUROPEAN COMMUNITY DIRECTIVE ON INSIDER TRADING
}

\author{
Thomas Lee Hazen*
}

\section{INTRODUCTION}

Since 1961, both the Securities and Exchange Commission ("SEC" or "the Commission") and the courts in the United States have been struggling in their attempts to define precisely what conduct constitutes improper trading on nonpublic information. ${ }^{1}$ As of 1992, neither Congress nor the Commission have been willing to take the bull by the horns and promulgate a definition. In contrast, in its Insider Trading Directive, the European Community ("EC") has made such a bold move." Much of the Directive is

Copyright (C) 1992 by Law and Contemporary Problems Hill.

* Cary C. Boshamer Distinguished Professor of Law, University of North Carolina at Chapel

1. SEC Rule 10b-5 was first used to combat insider trading in In the Matter of Cady Roberts, 40 SEC 907 (1961), where the Commission issued sanctions against a registered broker-dealer who, while in possession of information concerning a planned dividend cut, directed his customers to liquidate their holdings. The Commission held that this conduct "violated [Rule 10b-5(3)] as a practice which operated . . . as a fraud or deceit upon the purchasers." Id at 913 . The Commission continued:

Analytically, the obligation [to disclose the information or abstain from trading] rests on two principle elements: first, the existence of a relationship giving access, directly or indirectly, to information intended to be available only for a corporate purpose and not for the personal benefit of anyone, and second, the inherent unfairness involved where a party takes advantage of such information knowing it is unavailable to those with whom he is dealing.

Id at 912 .

2. Council Directive Coordinating Regulations on Insider Dealing, Directive 89/592, art 32 1989 OJ (L 334) 30, 1 Common Mkt Rep (CCH) \& 1761 ("EC Insider Trading Directive"). See generally Marjory Appel \& Gerhard Wegen, The EEC Directive on Insider Trading, 22 Rev SEC \& Commodities Reg 137 (1989); Christopher Cruickshank, Insider Trading in the EEC, 10 Intl Bus L 345 (1982); Raffaello Fornasier, The Directive on Insider Dealing, 13 Fordham Intl L J 149 (1989-90); Klaus Hopt, The European Insider Dealing Directive, 27 Common Mkt L Rev 51 (1990); Manning G. Warren, The Regulation of Insider Trading in the European Community, 48 Wash \& Lee L Rev 1037 (1991); Manning G. Warren, Global Harmonization of Securities Laws: The Achievements of the European Communities, 31 Harv Intl L J 185 (1990); Comment, Insider Trading and the EC: Harmonization of the Insider Trading Laws of the Member States, 8 BC Intl \& Comp L Rev 151 (1985) (authored by Lisa Hedges); Note, Toward the Unification of European Capital Markets: The EEC's Proposed Directive on Insider Trading, 11 Fordham Intl L J 432 (1988) (authored by Christine McGuinness); Note, Securities-Insider Trading-The Effects of the New EEC Draft Insider Trading Directive, 18 Ga J Intl \& Comp L 119 (1988) (authored by Douglas Nystrom); Note, Toward a Definition of Insider Trading, 41 Stan L Rev 337 (1989) (authored by Iman Anabtawi); Note, $A$ Comparative Analysis of the European Community Insider Trading Directive, 3 Transnatl $\mathrm{L}$ 
premised upon existing insider trading legislation. ${ }^{3}$ While the EC Directive borrows from concepts developed by U.S. courts, it provides a needed degree of certainty that is sorely lacking in U.S. law.

\section{U.S. LAW ON INSIDER TRADING}

In the United States, liability for trading on the basis of nonpublic information is premised primarily on an anti-fraud rule, SEC Rule 10b-5. Since Rule $10 \mathrm{~b}-5$ is grounded on fraud, the plaintiff must show that the information was used or given in violation of a fiduciary or comparable duty. ${ }^{4}$

Basing prohibitions against trading on nonpublic information upon a fiduciary or comparable duty has led to somewhat tortured analyses. For example, courts have found a Rule 10b-5 obligation based on the doctorpatient relationship 5 and, on appropriate facts, a familial relation-

231 (1990) (authored by Zachary Winner); Note, A New Look at the European Economic Community Directive on Insider Trading, 23 Vanderbilt J Transnatl L 135 (1990) (authored by Amy Stutz).

3. The varying approaches to insider trading regulation are discussed in Harvey L. Pitt \& David B. Hardison, Games Without Frontiers: Trends in the International Response to Insider Trading, 55 Law \& Contemp Probs 199 (Autumn 1992). See generally Barbara Banoff, The Regulation of Insider Trading in the United States, United Kingdom and Japan, 9 Mich Yearbook Intl Legal Stud 145 (1988); Joseph Blum, The Regulation of Insider Trading in Germany: Who's Afraid of Self-Restraint, $7 \mathrm{Nw}$ J Intl L \& Bus 507 (1986); Ronald Bornstein \& Elaine Dugger, International Regulation of Insider Trading, 1987 Colum Bus L Rev 375; Robert Briner, Insider Trading in Switzerland, 10 Intl Bus L 348 (1982); Francois Duhot, French Regulations on Disclosure Obligations and on Insider Trading, 2 Intl Bus L 96 (1974); Stephen Herne, Inside Information: Definitions in Australia, Canada, the UK and the US, $8 \mathrm{~J}$ Comp Bus \& Cap Mkt L 1 (1986); Klaus Hopt, Insider Trading on the Continent, 4 J Comp Corp L \& Sec Reg 379 (1982); Mary Houle, Survey of National Legislation Regulating Insider Trading, 9 Mich Yearbook Intl Legal Stud 209 (1988); Fenwick Huss \& Burt Leete, Insider Trading Regulations: A Comparison of Judicial and Statutory Sanctions, 25 Am Bus L J 301 (1987); Hans-Michael Kraus, Securities Regulation in Germany? Investors' Remedies for Misleading Statements by Issuers, 18 Intl L 109 (1984); James Lightburn, Insider Trading in France, 7 Intl Fin L Rev 23 (1988); Phillip Pillai, Current Developments in Insider Trading in Singapore and Malaysia, 16 Malaya L Rev 107 (1974); Edward Rosenbaum, et al, Corporate and Investment Attitudes Toward Insider Trading in Canada, 8 Can Bus L J 485 (1984); James Sarna, Japan and Insider Trading: Some Problems When There Are Different Definitions of Right and Wrong, 14 ILSA J Intl L 67 (1990); Misao Tatsuta, Enforcement of Japanese Securities Legislation, 1 J Comp Corp L \& Sec Reg 95, 112 (1978); Andre Tunc, The Reform of French Insider Trading Law, 4 Company L 205 (1983); Patrick Wallace, Who Is Subject to the Prohibition Against Insider Trading: A Comparative Study of American, British and French Law, 15 Sw U L Rev 217 (1985); Larry Zoglin, Insider Trading in Japan: A Challenge to the Integration of the Japanese Equity Market into the Global Securities Market, 1987 Colum Bus L Rev 419; Note, Insider Trading and the Internationalization of the Securities Markets, 27 Colum J Transnatl L 409 (1989) (authored by Michael Gerstenzang); Note, Regulation of Insider Trading in Hong Kong, 10 Hastings Intl \& Comp L Rev 647 (1987) (authored by Jonathan Gafni).

4. Chiarella v United States, 445 US 222 (1980). See also, for example, Bateman Eichler, Hill Richards, Inc. v Berner, 472 US 299, $311-12$ n21 (1985); Dirks v SEC, 463 US 646, 663 n23 (1983); United States $v$ Carpenter, 791 F2d 1024, aff'd by an equally divided Court, 484 US 19 (1987). See generally Barbara Aldave, The Misappropriation Theory: Carpenter and its Aftermath, 49 Ohio St L J 373 (1988).

5. In United States $v$ Willis, 737 F Supp 269 (SD NY 1990), a psychiatrist was indicted under Rule $10 \mathrm{~b}-5$ for allegedly trading on information obtained from a patient in the course of treatment. The patient was the spouse of a noted corporate executive, who was considering becoming chief executive officer of Bank America Corp. Armed with this information, the psychiatrist purchased Bank America stock. The court upheld the indictment since the psychiatrist received the information while in a position of trust and confidence, and breached that trust when he acted on that information for his personal benefit. The psychiatrist argued that since he was not directed to keep the information confidential, he could not be said to have violated any duty. The court rejected that 
ship. ${ }^{6}$ Thus, in United States $v$. Chestman, ${ }^{7}$ all eleven of the judges seemed to agree that a family relationship that is intertwined with a business relationship would be sufficient. Five of the eleven judges found such a confidential relationship based on marriage alone. Characterizing the husband-wife relationship as confidential is, of course, a defensible position. However, the folly of requiring such an antecedent relationship before applying the "disclose or abstain" rule should be evident. One cannot seriously contend that Congress enacted the securities laws to protect the sanctity of the doctor/patient, husband/wife, or father/son relationship or, for that matter, state law fiduciary duties of officers or managers to stockholders. To premise an insider trading violation on such a relationship is thus a quirk of U.S. law.

The primary basis of confusion in the United States is the extent to which Rule 10b-5 applies to persons who are not true insiders. There have been attempts to apply the rule to those who obtained the information from someone other than the issuer, and even to apply the rule to remote tippees. ${ }^{8}$ However, the cases have failed to provide a reasoned line of decisions. The confused, and in many instances conflicting, state of the law in the United States is easily exposed by examination of the facts in a few of the leading cases.

The Second Circuit has held that a printer of financial documents who traded on the basis of confidential information belonging to his employer did so in violation of Rule $10 \mathrm{~b}-5$ because he misappropriated the information. ${ }^{9}$ Four years earlier, in Chiarella $v$. United States, ${ }^{10}$ the Supreme Court had opened the door by indicating that although the knowing possession of information was not sufficient for a Rule $10 \mathrm{~b}-5$ violation, a showing that the information was "misappropriated" in breach of a fiduciary duty might be. 1 In a subsequent decision, the Supreme Court was split four to four in a case raising questions as to the vitality of the misappropriation theory of Rule $10 \mathrm{~b}$ 5 liability. ${ }^{12}$

argument, reasoning that the information that was passed on to the psychiatrist was confidential by its very nature, and thus he was not a remote tippee but rather breached a position of trust. Following the Second Circuit's decision in United States v. Chestman, 947 F2d 551 (2d Cir 1991) (en banc), the court permitted Dr. Willis to withdraw his guilty plea but then once again refused to dismiss the indictment. United States $v$ Willis, 23 Sec Reg \& L Rep (BNA) 1698 (1991). Following that decision, Dr. Willis reentered his guilty piea. See Psychiatrist Enters Second Guilty Plea to Charges He Traded on Patient's Data, 24 Sec Reg \& L Rep (BNA) 7 (1992).

6. Chestman, 947 F2d 551 (2d Cir 1991) (en banc).

7. Id. See generally Thomas L. Hazen, United States v. Chestman-Trading Securities on the Basis of Nonpublic Information in Advance of a Tender Offer, 57 Brooklyn L Rev 595 (1991).

8. See, for example, SEC $v$ Switzer, 590 F Supp 756 (WD Okla 1984) (ruling that Rule 10b-5 does not apply to someone overhearing a conversation containing material nonpublic information).

9. SEC v Materia, 745 F2d 197 (2d Cir 1984) (printer violated Rule 10b-5 by purchasing a target company's stock in reliance on nonpublic information obtained from client planning to make a tender offer).

10. 445 US $222(1980)$

11. Id at 232-35. See id at 238 (Stevens concurring).

12. United States $v$ Carpenter, 791 F2d 1024 (2d Cir 1986), aff'd in part and aff'd in part by an equally divided Court, 484 US 19 (1987) (conviction of Wall Street Journal reporter and friends for violations of the securities laws and federal Mail Fraud Act; the securities conviction was affirmed by an equally divided Court while the mail fraud conviction was unanimously affirmed). 
Dirks v. SEC was another decision in the wake of Chiarella where the Supreme Court had occasion to further elaborate upon the type of duty that is necessary to trigger the "disclose or abstain" obligation. ${ }^{13}$ In Dirks, the court held that a tippee of inside information will not be held accountable unless the tipper was himself or herself acting in violation of a fiduciary duty. ${ }^{14}$ Dirks involved an enforcement action against an investment advisor who had been informed by an inside whistleblower that Equity Funding Corporation was involved in serious accounting fraud (which subsequently led to the company's insolvency). After trying to alert the regulatory authorities, the defendant, Dirks, advised his clients to sell Equity Funding stock. The Court held that, since the information had not been passed on to Dirks for the purpose of improper insider trading, and since Dirks tried to help uncover the fraud prior to advising his clients, his passing on the information to his clients could not properly be said to be in violation of Rule 10b-5.15 The Court explained that "a tippee assumes a fiduciary duty to the shareholders of a corporation not to trade on material nonpublic information only when the insider has breached his fiduciary duty to the shareholders . . . and the tippee knows or should know that there has been a breach."16 Notwithstanding the confused state of the law in this country, it is clear that a remote tippee will not be liable under Rule $10 \mathrm{~b}-5,{ }^{17}$ although in the context of a tender offer, liability could be premised on Rule $14 \mathrm{e}-3$.

In Chestman, ${ }^{18}$ the defendant, Robert Chestman, a securities broker and financial advisor, learned from his client Keith Loeb that a tender offer was about to be made for the stock of Waldbaum, Inc. Loeb's wife was the niece of Waldbaum's president and controlling shareholder, Ira Waldbaum, who, along with his immediate family, owned a majority of the outstanding Waldbaum stock. Loeb was told by his wife, who had been told by her sister, that Waldbaum was about to be acquired. Loeb claimed he had told Chestman that he had reliable information that Waldbaum was going to be taken over and wanted to know what to do. Armed with this information, Chestman bought the stock for his own account. The district court held that Chestman knew this was a breach of duty. The divided Second Circuit panel held that without a showing that Loeb knew there had been a breach of fiduciary duty, there could be no $10 \mathrm{~b}-5$ violation. ${ }^{19}$ The panel, also by a twoto-one margin, held that Rule 14e-3, which applies on its face, would not be

13. 463 US 646 (1983).

14. Id at 659-61.

15. Id at 661-64.

16. Id at 660 .

17. SEC $v$ Switzer, 590 F Supp 756 (WD Okla 1984) (defendant who overheard insiders discussing nonpublic material information did not violate Rule $10 \mathrm{~b}-5$ by trading on the information since he did not breach any duty).

18. 947 F2d 551.

19. United States $v$ Chestman, 903 F2d 75, 78-80 (2d Cir 1990), rev'd, 947 F2d 555 (2d Cir 1991) (en banc). 
valid as applied to these facts. ${ }^{20}$ As noted above, when the Second Circuit heard the case en banc, it upheld the Rule 14e-3 conviction by an eleven-toone vote but overturned the Rule $10 \mathrm{~b}-5$ conviction by a six-to-five margin.

There have been some modest steps to free the premise of insider trading regulation from its contemporary dependence upon an antecedent fiduciary relationship. For example, the SEC's only attempt to define improper trading is found in Rule $14 \mathrm{e}-3$, which prohibits anyone other than a tender offeror or its affiliate from purchasing shares while in possession of material nonpublic information about a yet-to-be announced tender offer. ${ }^{21}$ Since Rule $14 \mathrm{e}-3$ is not couched in terms of an antifraud rule, it does not require breach of a duty; rather, it bases liability upon the possession and use of nonpublic information. ${ }^{22}$

Although provided with ample opportunities, Congress has shied away from addressing the problem directly. ${ }^{23}$ In the past, Congress has considered the imposition of a "possession" test that, as is the case with Rule 14e-3, would prohibit trading while in possession of material nonpublic information. ${ }^{24}$ Various observers have supported a "use" test which would have required proof that the trading was in fact based on the information. ${ }^{25}$ Opposition to a possession test was based in part on the argument that it cast too wide a net by prohibiting conduct that did not, in fact, involve misuse of information. The opponents of the proposed "use" test argued that it was inappropriate to impose liability for trading that was motivated by factors other than reliance upon the confidential information.

\section{III}

\section{The European Community Insider Trading Directive}

The EC Insider Trading Directive stands in stark contrast to the failed congressional effort to proscribe insider trading. The Directive establishes a minimum uniform standard for legislation in each of the member states. ${ }^{26}$ The directive confronts head-on the problem with which the courts in the

20. Id. Each of the three judges on the panel took a different approach to the Rule $14 \mathrm{e}-3 \mathrm{claim}$. Judge Minor would have sustained the conviction since, although the rule requires more than the mere possession of information, the prosecution had established more-namely, "that the trader [knew], or [had] reason to know, that the information was material and nonpublic and derive[d] directly or indirectly from an insider." 903 F2d at 84. Judge Carman was of the view that Rule 14e-3 can be violated only upon a showing of fraud; accordingly, he voted to reverse the conviction. Id at 87-88 (Carman concurring in part and dissenting in part). Judge Mahoney, who also voted for reversal, reasoned that since Rule $14 \mathrm{e}-3$ does not impose a fraud requirement by its terms, the rule is invalid. Id at 85 (Mahoney concurring in part and dissenting in part).

21. 17 CFR $\$ \S 240.14 \mathrm{e}-3$ (1991). This rule was promulgated in an attempt to overturn the impact of the Chiarella decision.

22. The validity of Rule 14e-3 was upheld by a ten to one decision in United States $v$ Chestman, 947 F2d 555 (2d Cir 1991) (en banc), rev'g 903 F2d 75 (2d Cir 1990).

23. See, for example, Pitt \& Hardison, 55 Law \& Contemp Probs at 200-01 (cited in note 3).

24. See H Rep No 98-355, 98th Cong, 2d Sess 9, 13-14 (1983), reprinted in 1983 USCCAN 2274, 2282-84 (Insider Trading Sanctions Act legislative history).

25. Id

26. EC Insider Trading Directive at preamble, art 6 (cited in note 2). 
United States have struggled since 1961-namely, the extent to which the prohibition extends to persons not in a fiduciary or other special relationship to the entity whose information is being used. The Directive not only defines "insider trading," but also categorizes various participants. The Directive sets forth four basic elements of the type of "inside information" that can form the basis of illegal trading: (1) the information is nonpublic; (2) the content is of a precise nature; (3) it relates either to an issuer of publicly traded securities (fundamental information) or to publicly traded securities (market information); and (4) if made public, the information would likely have a significant effect on the market price. ${ }^{27}$

The Directive divides persons who possess nonpublic information into two categories. "Primary" insiders are those persons who have acquired the information as a result of their employment or other direct positional access to the source of the information. ${ }^{28}$ "Secondary" insiders are those persons who have obtained the information, but not as a result of such a special relationship, from a source who was, directly or indirectly, a primary insider. ${ }^{29}$ Primary insiders are prohibited from either trading and tipping, whereas secondary insiders are prohibited from trading but are not subject to the antitipping prohibitions. This gap in the legislation may reflect the impracticality of detecting and successfully prosecuting remote tipping of nonpublic information. Nevertheless, the commentary is devoid of any explanation for not subjecting secondary insiders to the antitipping provisions. Consistency mandates extending the antitipping rules to remote parties, at least to those who knowingly make a selective disclosure of information that they know originated from a corporate insider and that they know is inside information.

Under the EC Directive, determination of improper trading is based not on a fiduciary duty, but rather on trading while in possession of the information. This is the rule for both primary and secondary insiders. ${ }^{30}$ In contrast, the antitipping rule is limited to primary insiders. Once it is established that a primary insider possesses material nonpublic information, he or she is prohibited from disclosing the information to a third party, unless such disclosure is in the normal course of the primary insider's employment, profession, or duties. ${ }^{31}$

The EC Directive attempts to strike a balance between the need to provide a clear and predictable rule and the fear of overregulating trading that does not present the pernicious effects of the unfair use of nonpublic information. The different tipping rules applicable to primary and secondary insiders may reflect an attempt to balance the need for effective insider trading enforcement against the risk of establishing too broad a prohibition. Another

\footnotetext{
27. Id at art $1(1)$.

28. Id at art $2(1)$.

29. Id at art 4.

30. Id at art $2(1), 4$.

31. Id at art 3(a).
} 
example of the desire to place limits on the scope of what is considered to be improper trading is found in the exclusions from the mandated trading prohibitions. While member states can, of course, decide to adopt more stringent legislation, they are not required to do so. Various activities are not addressed by the Directive. For example, the Directive does not prohibit a tender offeror or its affiliate in a control transaction from acquiring shares prior to announcement of a takeover attempt. ${ }^{32}$ Other practices not covered by the EC directive include: analyst estimates derived from publicly-available information, ${ }^{33}$ and legitimate market-making, brokerage, and stabilization activities by investment firms. ${ }^{34}$

As noted above, the United States stands to learn from the EC Directive's definition of improper trading. On the other hand, the Directive's attempt to eliminate material nonpublic information through its mandate that issuers disclose such information is not well designed. It is badly designed because, as described above, it leaves a gap in its coverage of secondary insiders. The EC Directive goes beyond insider trading by mandating issuer disclosure of material information. ${ }^{35}$ The intent of the provision is to reduce the frequency of insider trading by regulating one of the factors that contributes to the environment that facilitates personal gain on nonpublic information. The environmental factor is weak affirmative disclosure requirements for issuers. The affirmative disclosure mandate is designed to eliminate the existence of nonpublic material information. Although the New York and American Stock Exchanges have a similar rule, ${ }^{36}$ in practice, it is not effective because there may be important business reasons for keeping information confidential. Thus, for example, the Supreme Court has recognized that merger negotiations cannot be conducted in a fishbowl. ${ }^{37}$

It is questionable whether the $\mathrm{EC}$ affirmative disclosure mandate can or will have a significant effect in reducing insider trading. Furthermore, it puts companies in a most awkward position. Encouraging prompt disclosure is quite different from mandating it. Strict prohibitions against insiders who trade, coupled with an effective enforcement program, are adequate weapons

32. In contrast, SEC Rule 14e-3 expressly excludes bidder transactions from the reach of the rule's trading prohibitions. 17 CFR $\$ 240.14 \mathrm{e}-3$ (1991).

33. CCH Commentary on Control of Insider Dealing, 1 Common Mkt Rep (CCH) \9 1763, 1763.05 (Directive No 89/592).

34. Id. Other areas not covered include transaction by member states and/or their agents in furtherance of their monetary, exchange rate, or public debt management policies; brokers with insider information whose activities are limited to carrying out customers' instructions; stabilizing activities in connection with pricing of primary and secondary offerings; transactions based on estimates deprived from publicly available data; and communication of inside information to an enforcement authority. Id.

35. EC Insider Trading Directive at art 7 (cited in note 2).

36. New York Stock Exchange Company Manual $\S 202.05,202.06,3$ Fed Secur L Rptr (CCH) II $23,519,23,520$ (1989). See also American Stock Exchange Company Guide $\$ \S 401,402,2$ Am Stock Exchange Guide (CCH) ๆ 10,121-10,122 (1992).

37. Basic, Inc, $v$ Levinson, 485 US 224 (1988). The rule in this country is that while a company cannot make materially misleading statements, it can simply refuse to make any comment. Id; see Thomas L. Hazen, Rumor Control and Disclosure of Merger Negotiations or Other Control-Related Transactions: Full Disclosure or "No Comment"-The Only Safe Harbors, 46 Md L Rev 954 (1987). 
against trading on the basis of material nonpublic information. Although some observers might quibble with the location of the EC Directive's lines, at least the lines are clearly drawn.

\section{IV}

\section{a Comparison of the United States Law on Insider Trading AND THE EC DiRective}

The clear definitional approach taken by the Directive is preferable to the murky rule in this country. Not only does the Directive provide certainty and predictability, it is capable of handling the difficult question of the liability of persons other than true insiders.

The advantages of the Directive are evident from examining how it would be applied to the facts of some of the key cases in this country. As is the case in the United States, true insiders are prohibited from trading on inside information. ${ }^{38}$ Similarly, insiders are not permitted to pass the information on to others for their personal gain or for the purpose of improper trading by the tippees. ${ }^{39}$ In Chiarella, the printer would qualify as a primary insider under the EC directive and thus would be prohibited both from trading on the information and from passing it on to someone else. The psychiatrist who trades on information provided by a patient would qualify as a primary insider because he had access to the information "by virtue of the exercise of his employment, profession, or duties." 40 This language would not include a family relationship and thus would track Chestman insofar as it would not find that the customer who obtained the information from his wife was more than a secondary insider and thus could not be liable for tipping (as opposed to trading on) the information. On the other hand, the broker obtained the information in the course of his employment and thus would seem to qualify as a primary insider under the EC directive and hence would be precluded from either trading or tipping.

A major difference between the EC Directive and the law in the United States is that the Directive would apply to remote tippees. A remote tippee who overhears the information, knowing it to be material and nonpublic, would qualify as a secondary insider since the "direct or indirect source of [the information] could not be other than a [primary insider]." 41 The Directive thus focuses on the source of the information, not on whether the source breached a duty in passing on the information. ${ }^{42}$ Congress stands to benefit from the EC's lesson if it is willing to adopt a definition that focuses on

38. See SEC v Texas Gulf Sulphur Co., 401 F2d 833 (2d Cir 1968).

39. See United States $v$ Carpenter, 791 F2d 1024, aff'd by an equally divided Court, 484 US 19

(1987). Compare Dirks v SEC, 463 US 646 (1983) (discussing in dictum the scope of tippee liability).

40. EC Insider Trading Directive at art $2 \S 1$ (cited in note 2).

41. Id at art 4. Compare SEC v Switzer, 590 F Supp 756 (WD Okla 1984) (remote tippee is not liable). See also Dirks $v$ SEC, 463 US 646, 663 (tippee not liable without showing that the tipper breached a duty).

42. Compare Dirks v SEC, 463 US 646, 663 (indicating that for a tippee to be liable, the tip must be tainted with a breach of duty). 
possession and use of information rather than on a duty tied to a fraud-based rule.

\section{V}

\section{Conclusion}

The EC has accomplished something that the U.S. Congress has not been able to accomplish. By defining specifically the persons and transactions covered by insider trading prohibitions, the EC Directive provides certainty in the rule of law not found in the United States counterpart. Interestingly, much of the theory underlying the EC Directive was adopted from the United States case law. Congress should follow the EC approach and codify the law, thereby providing needed certainty and coherence. 
